Yevhen Kozak,

PhD (Candidate of Pedagogical Sciences), associate professor of the Department of Sports and Sports Games, Ivan Ogienko National University of Kamyanets-Podilsky, 61, Ogienko Street, Kamyanets-Podilsky, Ukraine

Olena Bosenko, teacher, Municipal Institution "Odessa Pedagogical Professional College", 1, Gretska Street, Odessa, Ukraine

\title{
ADVANCE IN THE METHOD OF MANUFACTURE AND USE OF EXPRESS DIABETIC HONEY FOR HEALTH IMPROVEMENT
}

The article is devoted to the problem of making express diabetic honey to prevent and improve health, as well as to treat diabetic individuals. The disease has become extremely widespread both globally and in individual countries. It was registered that over 425 million people have diabetes for the current year. According to this situation, the medical expenses reach up to 727 billion US dollars, which could be spent to the improvement of the quality of living standards. The number of cases of diabetes is about 1.3 million adults against the backdrop of difficult demographic situation in Ukraine. Unfortunately, there is a negative trend in our country towards the spread of the disease among young people and children, even preschoolers. In accordance with a prognostic point of view, the prospect of today's young generation seems highly undesirable - that is, to be among people with this pathology all their lives. Therefore, solving the problem through prevention and healthy lifestyle is important. Due to shortages of medicines and financial support for certain population category, the solution in this case is seen in the expansion of folk remedies for prevention and treatment, the leading place among which are bee products. The aim of the study was to develop a method of making diabetic express honey from blueberries (Vaccinium myrtillus L.), Jerusalem artichoke (Helianthus tuberosus L.), common beans (Phaseolus vulgaris L.) and to study its effect on changes in glucose, total protein and plasma protein fractions (PPF) of diabetics. According to studies of two groups of males (control and experimental) aged 50-70 years with a total of 24 people, it was found that the use of developed by the author's methodology of express diabetic honey from blueberries, Jerusalem artichokes and common beans helps to stabilize blood glucose levels; it has a positive effect on protein metabolism and immunity of diabetics, as well as enhances the effect of oral antidiabetic drugs.

Keywords: express diabetic honey, diabetes, protein, blood plasma, glucose.

Подано до редакиіï 24.11.2021

УДК: $159.922 .8: 316.612: 159.961 .8$

DOI: https://doi.org/10.24195/2414-4665-2021-4-5

Олена Косьянова,

кандидат психологічних наук, дочент кафедри теорії та методики практичної психології, Державний заклад «Південноукрайнський начіональний педагогічний університет імені К. Д. Уиинського», вул. Старопортофранківська, 26, м. Одеса, Україна,

олена Назарук,

здобувач вищої освіти ІІ магістерського рівня зі спеціальності 053 Психологія,

Державний заклад «Південноукраӥнський національний педагогічний університет імені К. Д. Уиинського», вул. Старопортофранківська, 26, м. Одеса, Україна

\section{ОСОБЛИВОСТІ ЗАДОВОЛЕНОСТІ ЖИТТЯМ ТА ОМАНЛИВОСТІ В ЮНАЦЬКОМУ ВІЦІ}

В останні десятиліття багатьма дослідниками в різних областях психології, а також не пов'язаними з психологічними дослідженнями спеціалістами, такими як: соиіологи, політологи, економісти, розглядається такий феномен, як задоволеність життям. Також зростає зацікавленість задоволеністю життям $i$ в прикладному аспекті. Найчастіше стан особистості в психологічному значенні визначається емоційною стабільністю, стресостійкістю, високою мотивачією, отже, одним словом, гармонійними відносинами в навколишньому світі та з самим собою. Перед дослідниками постає питання: «Яким чином можливо досягти задоленістю життям, використовуючи такий гармонійний контструкт?». Задоволеність життям може 
виступати як постійна особливість і як інструмент задля досягнення та реалізації життєвого шляху людини взагалі. У психологічних дослідженнях ией феномен пов'язаний з такими іменами, як: М. Аргайл, А.Маслоу, В.Франкл, Р.P Мей, С. Бенко, Е. Dіепег та іншими. Відносно загальної задоволеності життям, яке тісно пов'язано із задоволеністю важливих сферах життя (самооцінка; сім'я; дружба; сочіальні аспекти, такі як: робота, учбова діяльність; економічний та соціальний статуси, та ін.). Водночас усі иі сфери життя людини тісно пов'язані ще з одним феноменоменом - оманливістю особистості. Особливо важливо, як показують дослідження різних вікових періодів, ия характерологічна особливість особистості проявляється в юнацькому віці. Саме в иуьому віці схильність до обману може вплинути на стратегії поведінки в майбутньому та відкласти слід на всьому життевому иляху. Метою иього дослідження був пошук особливостей задоволенності життям та специифіки оманливості особистості в юнацькому вічі. Всього в дослідженні приймали участь 48 осіб юнацького віку від 18 до 23 років. Методи дослідження: теоретичні (класифікація, структуризація та аналіз підходів до вивчення і розуміння омани та задоволеності життям у психологічній літературі); емпіричні (тестові методики: опитувальник задоволеність життям М. М. Мельникової, шкала «Задоволеність життям» E. Дінера (SWSL) (1985); багатомірно-функціональна діагностика брехні (В. П. Прядеїн, І. А. Церковнікова), «Мотиви брехні» I. П. Шкуратової; «Причини брехні» I. П. Шкуратової, а також математико-статистичні (обробка даних зроблена за допомогою програми «Microsoft Excel», «SPSS 26.0 для Windows ХР»). Проведений кореляиійний аналіз виявив наявність значимих додатних та від’ємних зв'язків на рівні 1\% та 5\% між показниками причин та мотивації омани, їі складових із задоволеністю життям. Отримані кореляційні зв'язки підтверджують припущення щзодо взаємопов'язаності та взаємовпливі досліджуваних показників омани та задоволеності життям. Визначено групи осіб з високим і низьким рівнем задоволеності життям (за Е. Дінером): група з високим значенням показника загального рівня задоволеності життям, (ВЗЖ, $n=12)$ та група з низьким значенням показника загального рівня задоволеності життям (НЗЖ, $n=16)$, щзо дало змогу дослідити психологічні особливості прояву обману, мотивації щзодо застосування омани у повсякденному житті у будь-яких сферах життедіяльності та вивчення особливості змістовного наповнення компонентів оманливості у представників юнацького віку.

Ключові слова: задоволеність життям, оманливість особистості, мотиви та причини брехні, загальний рівень задоволеності життям.

\section{блеми}

Вступ та сучасний стан досліджуваної про-

Звичайне поняття «задоволеність життям» неоднозначне. Воно часто використовується лише для опису того, що відчуває людина, тобто конкретного феноменологічного стану людини. Це той стан, в якому ми знаходимося, коли відчуваємо задоволення, ейфорію тощо. Більшість 3 нас мали безпосередній досвід такого відчуття задоволеності життям. Наприклад, ми зазвичай відчуваємо задоволеність життям, коли несподівано розуміємо, що все гаразд і життя іде по наміченому плану. Коли термін «задоволеность життям» використовується в цьому першому значенні, нічого більше не потрібно, щоб бути задоволеним, ніж відчувати себе щасливим або бути в щасливому настрої (Бенко, 2015). Таку задоволеність життям називають «психологічною» (або «місцевою») задоволеністю життям (Селігман, 2006).

Крім того, деякі філософи, такі як Фельдман (2008), використовують термін «задоволеність життям» у третьому значенні. Коли вони говорять про задоволеність життям особистості, вони мають на увазі лише те, що вона живе добре. Крім того, вони розуміють, що життя $є$ хорошим, якщо воно має високий рівень добробуту (Goldbeck, 2007).

Одним 3 основних компонентів особистісного благополуччя, більшістю дослідниками, вважається задоволеність життям, яке може розглядатися як усвідомлена оцінка свого життя (Джидар'ян, 2013). Так, при проведенні досліджень особистісне благополуччя та задоволеність життям найчастіше ототожнюється досліджуваними (Любомірскі, 2014).
На відміну від загальної задоволеності життям, яке тісно пов'язано із задоволеністю важливих його сферах (Аргайл, 2003; Балацький, 2005).

Поширена думка, що залежність задоволеності життям від віку має «U- образну форму», причому задоволеність життям знижується до середнього віку, а потім зростає (Glenn, 2009). Група вищезгаданих вчених повідомляє про результати масштабного міжнаціонального дослідження вікових періодів та задоволеності життям і приходять до висновку, що у більшості вивчених суспільств благополуччя зазвичай буває високим у молодому i літньому віці та найнижчим у віці близько 40 років. Більшість дослідників, що вивчають взаємозв'язок між станом в шлюбі і задоволеністю життям, вважають, що останнє впливає на сімейний стан - щасливіші люди з більшою вірогідністю одружилися i продовжують жити щасливим сімейним життям. Дохід i освіта, викликають підозру, як фактори, оскільки взаємозв'язок між ними і благополуччям може бути частково неправданим. У цього роду дослідженнях основна контрольна змінна - це лонгітюдне дослідження, яке дозволяє вивчати зміну благополуччя людей упродовж їх життєвого шляху. Так само проводилися відтворюючі дослідження в США 3 даними про щастя i так само було отримано підтвердження того, що результати наближаються до U- образної моделі (Glenn, 2009).

Інша ж група учених частково спростовує явище U- образної моделі та в своїх дослідженнях показує, що немає загальної вікової тенденції в задоволеності життям (Bartram, 2021). Підрахунок балів задоволення життям дається у відповідь на питання: «3 
урахуванням усіх обставин, наскільки ви задоволені своїм життям загалом у ці дні»? Респонденти вибирають число від 1 до 10, де 1 - «повністю не задоволений», а 10 - «повністю задоволений» (проміжні числа не помічені). Відповідними елементами контролю в цьому контексті є суспільство, період дослідження i країна, кожна 3 яких може впливати на віковий склад населення, а також на задоволеність життям. Вплив країни на віковий склад очевидний через значні міжнародні відмінності в очікуваній тривалості життя. Статистичний аналіз отриманих даних показує, що задоволеність життям дійсно знижується в юнацькому віці - в середньому на 0,0082 балів в рік за 10-бальною шкалою. Це не дуже «значне» число в основному сенсі, і схоже це реальне зменшення. Ключове виведення полягає в тому, що у кращому разі спостерігається незначне зростання задоволеності життям після досягнення середнього віку - і важливе значення полягає в тому, що в цьому випадку не може бути U-образного зв'язку між віком і задоволеністю життям (Bartram, 2021).

Інтелект також $\epsilon$ важливимчинником, тому щозадоволеність життям у міру того, як люди стають старше; у міру того, як вони стають старше, вони стають мудріше обізнанішими, ікраще розуміють важливіречі в житті (Diener, 1999; Goldbeck, 2007).

Водночас усі ці сфери життя людини тісно пов'язані ще $з$ одним феноменоменом - оманливістю особистості (Баришполець, 2013). Особливо важливо, як показують дослідження різних вікових періодів, ця характерологічна особливість особистості проявляється в юнацькому віці (Зинченко, 2005). Саме в цьому віці схильність до обману може вплинути на стратегії поведінки в майбутньому та відкласти слід на всьому життєвому шляху (Знаков, 2013; Косьянова, Чебикін, 2017). На жаль, практично відсутні дослідження, в яких би досліджувався взаємозв'язок цих явищ. Отже, в нашій роботі ми зробимо спробу виявити особливості задоволенності життям та специфіки оманливості особистості.

Метою цього дослідження є пошук особливостей задоволенності життям та специфіки оманливості особистості в юнацькому віці. Відповідно до мети нами сформовано наступні задачі дослідження.

1. Проаналізувати теоретико - методологічні підходи до розуміння задоволеності життям.

2. Розкрити основні поняття в області психології обману, а також клафифікацію основних мотивів та причин обману.

3. Розглянути специфіку схильності юнаків до оманливості та розуміння ними задоволеності життям.

4. Дослідити особливості прояву задоволеності життям та оманливості у юнацькому віці.

Об'єкт дослідження: оманливість та сфера задоволеності життям - Предмет дослідження: взаємозв'язок задоволенності життям та специфіки оманливості особистості в юнацькому віці. Гіпотези. 1. Задоволеність життям юнаків пов'язана 3 особливостями оманливості особистості, що відповідає прийнятим в соціумі традиційним нормам. 2. Між причинами та мотивами омани існує певний взаємозв'язок, що виявляється в різних сферах життя особистості. Розкриття специфіки зв'язків дозволить не тільки поглибити пізнання проблеми, а також сприяти розробці більш адекватних профілей та підходів в педагогічно - виховному процесі юнаків.

\section{Методи та організація дослідження}

Для досягнення поставленої мети дослідження було використано теоретичні методи: аналіз, узагальнення, систематизація відомостей щодо проблеми, яка порушується в дослідженні. Для проведення емпіричного дослідження було використано комплекс психодіагностичних методик. Першою методикою нами обрана Шкала «Задоволеність життям» Е. Дінера (SWSL) (1985). Роботи Е. Дінера стали важливим вкладом в проблему розуміння феномену «суб'єктивного благополуччя», яке, на думку дослідника, складається 3 трьох основних компонентів: задоволення, приємні емоції (pleasant affect) i неприємні емоції (unpleasant affect) (Райгородський, 2001). Суб'єктивне благополуччя покликане не просто служити індикатором того, наскільки людина занурена в депресію або тривогу, але повинно демонструвати наскільки одна людина щасливіша за іншу. Е. Дінером у відповідність з його теоретичною концепцією суб'єктивного благополуччя була розроблена Шкала «Задоволеність життям». За кордоном ця шакала систематично використовуються в масових опитуваннях i міжнаціональних моніторингах. Шкала задоволеності життям вимірює когнітивну оцінку відповідності життєвих обставин очікуванням індивіда i відбиває загальну міру внутрішньої гармонії і психологічної задоволеності. Показник задоволеності життям виявляє дещо слабкіші взаємозв'язки 3 іншими заходами суб'єктивного благополуччя, проте слід чекати, що він буде тісніший взаємозв'язаний 3 об'єктивними показниками успішності життя індивіда.

Опитувальник задоволеність життям М. M. Мельникової розроблений лабораторією соціальнопсихологічної адаптації особистості при кафедрі соціальної психології Південно-Уральського державного університету під керівництвом Мельниковой Н. Н. У 2001 p. пройшов повну психометричну перевірку на валідність і надійність, стандартизований. Опитувальник спрямований на вивчення суб'єктивного почуття задоволеності життям i може бути використаний для діагностики дорослих випробовуваних у віці від 18 до 55 років. Задоволеність життям розглядається як суб'єктивно переживаний стан, що є реакцією на якість взаємодії Я - Життя. У рамках суб'єктивного досвіду людини ознаками задоволеності - незадоволенню життям $є$ :

- загальний емоційний стан у зв'язку з життєвою ситуацією; 
- динамічний компонент життєдіяльності (активність - пасивність, наявність прагнень, бажань);

- почуття насиченості - порожнечі життя;

- задоволеність, пов'язана з реалізацією планів, задоволенням потреб;

- відчуття стабільності - нестабільності навколишнього світу, очікування від майбутнього.

Багатомірно-функціональна діагностика брехні (В. П. Прядеїн, І. А. Церковнікова) фіксує різні параметри щирості досліджуваних. Так, показник динамічної ергічності показує нещирість, що демонструється в активності, оперативності, самостійності та прагеннні бути краще. При прояві динамічної аергічності нещирість проявляється в запереченні самостійності, активності, страху викриття. Емоційна стенічність показує нещирість, що демонструється в більшому проявленні позитивних емоцій, таких як радість та задоволення. Емоційна астенічність - заперечення негативних емоцій: гнів, грубість, злість. Регуляторна інтернальність нещирість проявляється в самокритиці, серйозності особистісних рішень та демонстрації незалежності від інших, самозначимості. Регуляторна екстернальність нещирість проявляється в запереченні своєї залежності від інших людей чи обставин та в невиповнені особистісних обов'язків. Також мотиваційна соціоцентричність, мотиваційна егоцентричність, когнітивна осмисленість та когнітивна поінформованість, результативна предметність та результативна суб'єктність (Прядеїн, 2014; Церковнікова, 2005).

«Мотиви брехні» І. П. Шкуратової - ця методика містить твердження, пов'язані з приписуванням різних мотивів брехні. Чим більше людина називає різних мотивів, тим більше вона мотивована на спотворення інформації.

Згідно мети наступної використовуваної методики «Причини брехні» респонденти повині оцінити які саме причини спотворення інформації $\epsilon$ найголовнішими на їх погляд: людям найчастіше доводиться дурити заради того, щоб не зіпсувати враження про себе; люди спотворюють інформацію про себе, щоб оточуючі не контролювали їхнє життя; людям доводиться дурити близьких, щоб не засмучувати їх; людям доводиться спотворювати інформацію про себе, ніж зіпсувати відносин із оточуючими; люди часто спотворюють інформацію про себе, бо бояться закидів з боку оточуючих; при знайомстві люди часто прикрашають себе, щоб створити гарне враження себе (Шкуратова, Крікало, 2007).

Всього в дослідженні приймали участь 48 осіб юнацького віку від 18 до 23 років, з яких: 12 чоловічої статі та 36 - жіночої. Дослідження проводилося 3 квітня по травень 2021 року, в один етап. Випробовуваним пропонувалося пройти комплекс методик за необмежену кількість часу, бажано в межах доби.

\section{Результати та їх обговорення}

Наступним кроком було визначення кореляційних зв'язків між показниками причин омани та факторами задоволеності життям. Для визначення взаємозв'язку з суб'єктивною задоволеністю життям та оманливістю було застосовано опитувальник «Задоволеність життям» Н. Мельнікової.

Таблиця 1

Значимі коеріцієнти кореляції між показниками

причин омани та показниками задоволеності жситтям (за Н. Мельніковою)

\begin{tabular}{|c|c|c|c|c|}
\hline \multirow{2}{*}{$\begin{array}{c}\text { Показники } \\
\text { задоволеності } \\
\text { життям } \\
\text { (Н. Мельнікова) }\end{array}$} & \multicolumn{4}{|c|}{ Показники причин омани } \\
\hline & Ш1 & Ш3 & Ш4 & Ш5 \\
\hline F1 & $-368 * *$ & $-344 * *$ & $-314 * *$ & $311 * *$ \\
\hline $\mathrm{F} 2$ & $277 *$ & $-444 * *$ & & \\
\hline F3 & & $316^{* *}$ & $229 *$ & \\
\hline
\end{tabular}

Примітки. 1) Умовні скорочення показників причин омани: Ш1 - людям найчастіше доводиться обманювати заради того, щчоб не зіпсувати враження про себе, ШЗ - людям доводиться обманювати близьких, щьоб не засмучувати їх, Ш4 - людям доводиться спотворювати інформацію про себе, щчоб не зіпсувати відносин із оточуючими, Ш5 - люди часто спотворюють інформацію про себе, тому щзо бояться закидів з боку оточуючих. 2) F1 - життєва включеність, F2 - розчарування у житті, F3 - втома від життя, F4 - занепокоєння про майбутнє, ЗП-загальний показник задоволеності життям.

Показник життєва включеність (F1) виявив від'ємний зв'язок з показниками причин омани: Ш1 (людям найчастіше доводиться обманювати заради того, щоб не зіпсувати враження про себе) (r=-368; при $\mathrm{p}=0,01$ ), Ш3 (людям доводиться обманювати близьких, щоб не засмучувати їх) (r=-344; при $\mathrm{p}=0,01)$, Ш4 (людям доводиться спотворювати інформацію про себе, щоб не зіпсувати відносин із оточуючими) (r=-314; при $\mathrm{p}=0,01)$ і додатний зв'язок $з$ показником Ш5 (люди часто спотворюють інформацію про себе, тому що бояться закидів з боку оточуючих) (r=311; при $\mathrm{p}=0,01)$. Показник розчарування у житті (F2) виявив додатний зв'язок 3 показником Ш1 (людям найчастіше доводиться обманювати заради того, щоб не зіпсувати враження про себе) (r=277; при $\mathrm{p}=0,05)$ та від'ємний зв'язок з показником Ш3 (людям доводиться обманю- 
вати близьких, щоб не засмучувати їх) (r=-444; при $\mathrm{p}=0,01)$. Показник втома від життя (F3) отримав додатні зв'язки з показниками Ш3 (людям доводиться обманювати близьких, щоб не засмучувати їх) (r=316; при $\mathrm{p}=0,01)$, Ш4 (людям доводиться спотворювати інформацію про себе, щоб не зіпсувати відносин із оточуючими) (r=229; при p=0,05).

Таблиця 2

Значимі коефіціснти кореляції між показниками

причин та показниками задоволеності життям (за Е. Дінером)

\begin{tabular}{|c|c|c|}
\hline \multirow{2}{*}{$\begin{array}{c}\text { Показник } \\
\text { задоволеності } \\
\text { життям }\end{array}$} & Шоказники причин омани \\
\cline { 2 - 3 } (Е Дінера) & & Ш4 \\
\hline ЗРЗЖ & $242^{*}$ & $-396^{*}$ \\
\hline
\end{tabular}

Примітки. Умовні скорочення: ЗРЗЖ-загальний показник задоволеності життям

Загальний показник задоволеність життям (за методикою Е. Дінера) ЗПЗЖ виявив додатний зв'язок 3 показником Ш2 (люди спотворюють інформацію про себе, щоб оточуючі не контролювали їхне життя) $(\mathrm{r}=242$; при $\mathrm{p}=0,05)$ і від'ємний зв'язок з показником Ш4 (людям доводиться спотворювати інформацію про себе, щоб не зіпсувати відносин із оточуючими) ( $\mathrm{r}=369$; при $\mathrm{p}=0,01)$.

Таким чином, проведений кореляційний аналіз показав взаємопов’язаність показників, що характери- зують причини омани, мотиви омани та іï компонентів із задоволеністю життям.

Вибірка досліджуваних, яка налічує 48 осіб юнацького віку за результатами діагностики за шкалою задоволеності життям (Е. Дінера) була поділена на групи 3 високим, середнім та низьким рівнем. На рис. 3.3.1 надано результати розподілу досліджуваних відповідно до значення загального показника задоволеності життям (Е. Дінера).

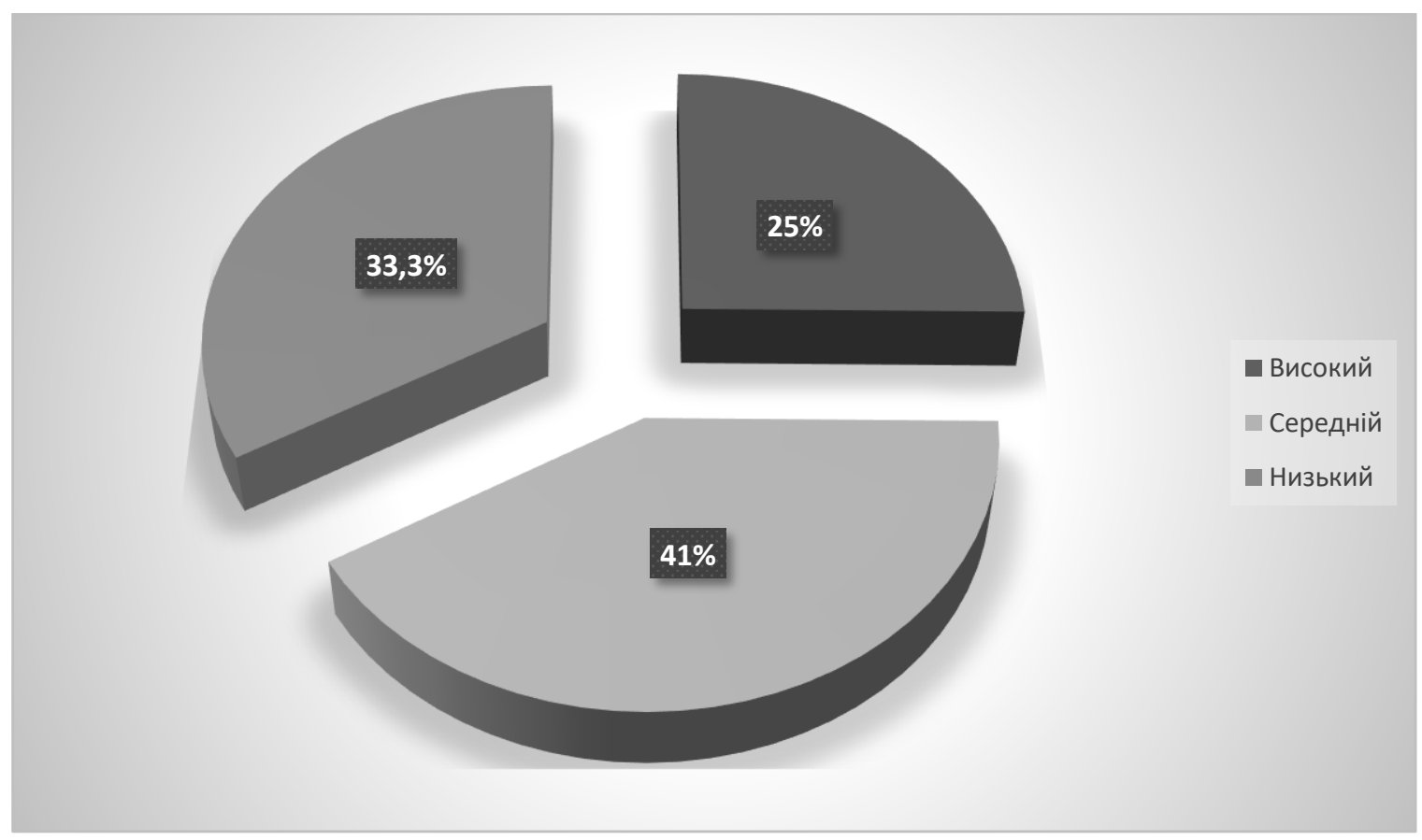

Рис. 1. Діаграма розподілу груп з високим, середнім та низьким рівнем задоволеності життям (Е. Дінера).

У подальшому дослідженні вивчення психологічних особливостей прояву оманливості проводилось в групі респондентів 3 високим та низьким рівнем задоволеності життям. На рис. 2 зображено гістограму результатів діагностики показників задоволеності життям (Н. Мельнікова) в групах з високим та низьким рівнем. 


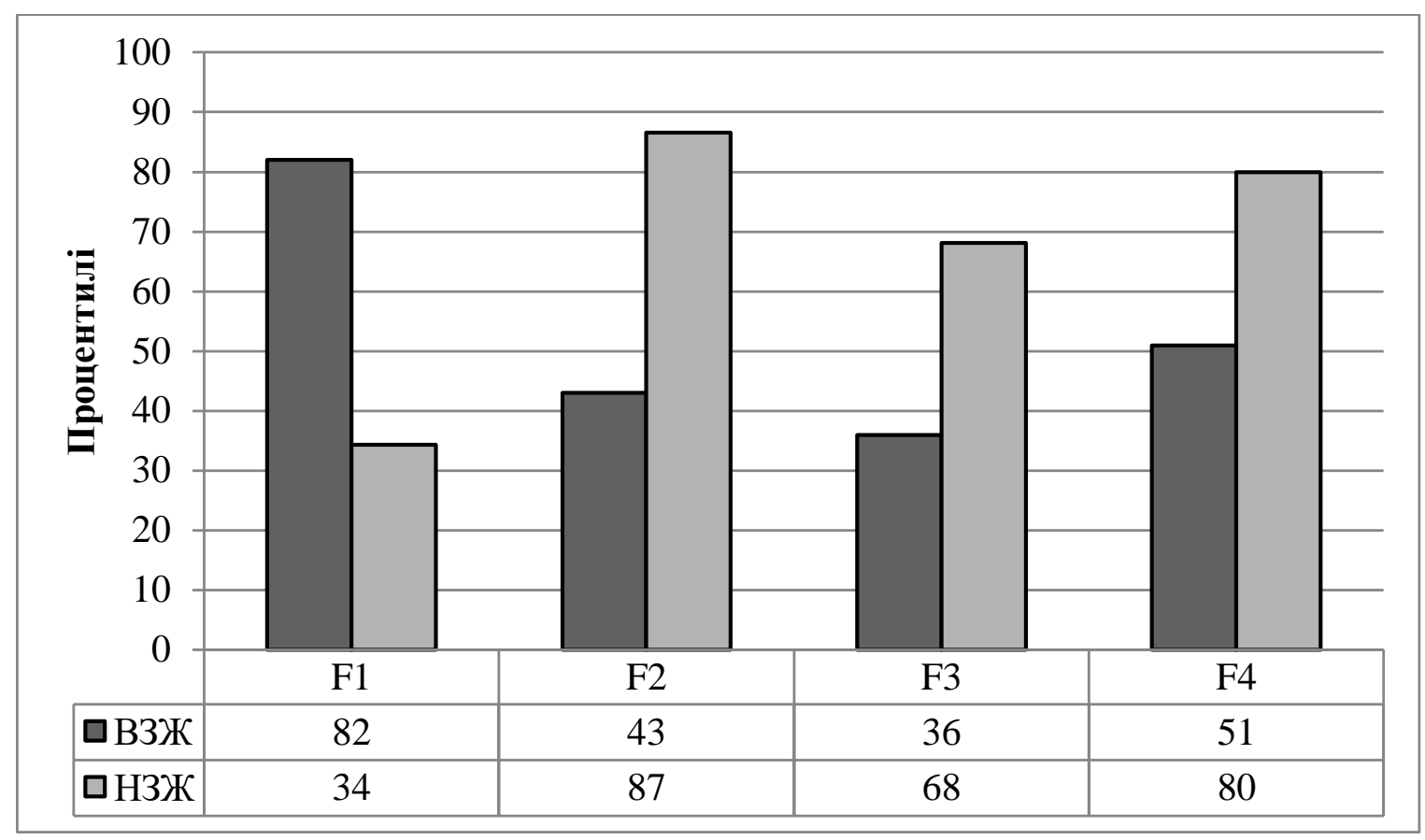

Рис. 2. Гістограма результатів діагностики показників задоволеності життям (Н. Мельнікова) в групах з високим та низьким рівнем

Примітки. Умовні скорочення: ВЗЖ - високий рівень задоволеності життям, НЗЖ - низький рівень задоволеності життям; F1 - життєва включеність, F2 - розчарування у житті, F3 - втома від життя, F4 - занепокоєння про майбутнє.

Тут і надалі на осі ОХ відмічені показники, щзо вивчаються, на осі ОY - ̈̈х значення в прочентилях. Значення кожного показника є середнє арифметичне число конкретного показника усіх представників кожної групи окремо. Діапазон від 0 до 25 (периий квартіль розподілу Q1) вважається простором низьких значень показника; від 25 до 50 - простором слабо виразних значень (другий квартіль розподілу Q2); від 50 до 75 - діапазоном достатньо виразних значень (третій квартіль розподілу Q3); від 75 до 100 - діапазоном яскраво виразних значень показника (четвертий квартіль розподілу Q4). Середня лінія ряду проходить через 50 прочентиль.

Отже, визначено що у досліджуваних групи з високим рівнем задоволеності життям (ВЗЖ) більш вираженим є фактор F1 «життєва включеність», що свідчить про важливість для цих осіб мати відчуття насиченості, повноти життя, прагнення до дій із перспективою на майбутнє, наявність та виразність таких позитивних станів, як радість, задоволення, душевна рівновага. Найменш виражений у респондентів фактор F2 «втомлюваність від життя», тобто присутнє певне відчуття апатичності стосовно життя, втрата сил, виснаженість та відчуття того, що життя проходить повз.

Для респондентів групи з низьким рівнем задоволеності життям (НЗЖ) найбільш виражений фактор F2 розчарування у житті та F4 занепокоєння про майбутнє. Це вказує на переживання розчарування, досади, образи, відчуття несправедливості через розбіжність бажаного 3 дійсним, коли докладені зусилля не досягають мети. Представникам групи притаманне незадоволеність діяльністю та реалізацією, відчуття відсутності результатів, неможливість реалізації планів, відсутність перспектив, що виражають тривожні очікування несприятливих життєвих подій і невпевненість у завтрашньому дні, пов'язані з почуттям нестабільності навколишнього світу та відчуттям небезпеки.

Згідно концепції одного 3 авторів методики I. А. Церковної, оманливість як індивідуально-психо- логічна властивість особистості полягає у спотворенні інформації, проявляється в операційній та змістовній сферах, має широку варіативність. 3 позицій багатовимірно-функціонального аналізу в брехливості виділено функціональну єдність мотиваційного, емоційного, когнітивного, динамічного, регуляторного, результативного компонентів та визначено полярність їх складових (ергічність-аергічність, стеничність-астенічність, інтернальність-екстернальність, предметність-суб'єктність).

Отже, для представників групи з високим рівнем задоволеності життям характерні емоційна астенічність (ЕАС), що проявляється нещирістю, запереченні негативних емоцій: гніву, злості, грубості. Когнітивний компонент оманливості розглядається 3 позиції осмисленості та обізнаності. У представників цієї групи обізнаність (КОБ) характеризує оманливе заперечення своєї непоінформованості під час прийняття рішень.

Результативний компонент оманливості розглядається у комунікативній (предметній) та суб'єктивній сферах. Для респондентів з високим рівнем задоволеності життям суб'єктна змінна характеризує оманливе заперечення спрямованості на особистісно-значимий результат, нездатність до самореалізації (РС). Також ці особи демонструють соціометричну мотивацію, що 
можна розглядати як брехливу демонстрацію власної значущості у вирішенні суспільних питань, конфліктах, що виражена у бажанні бути серед людей, колек- тиву, суспільства, переважанням суспільних інтересів над особистими інтересами (МC).

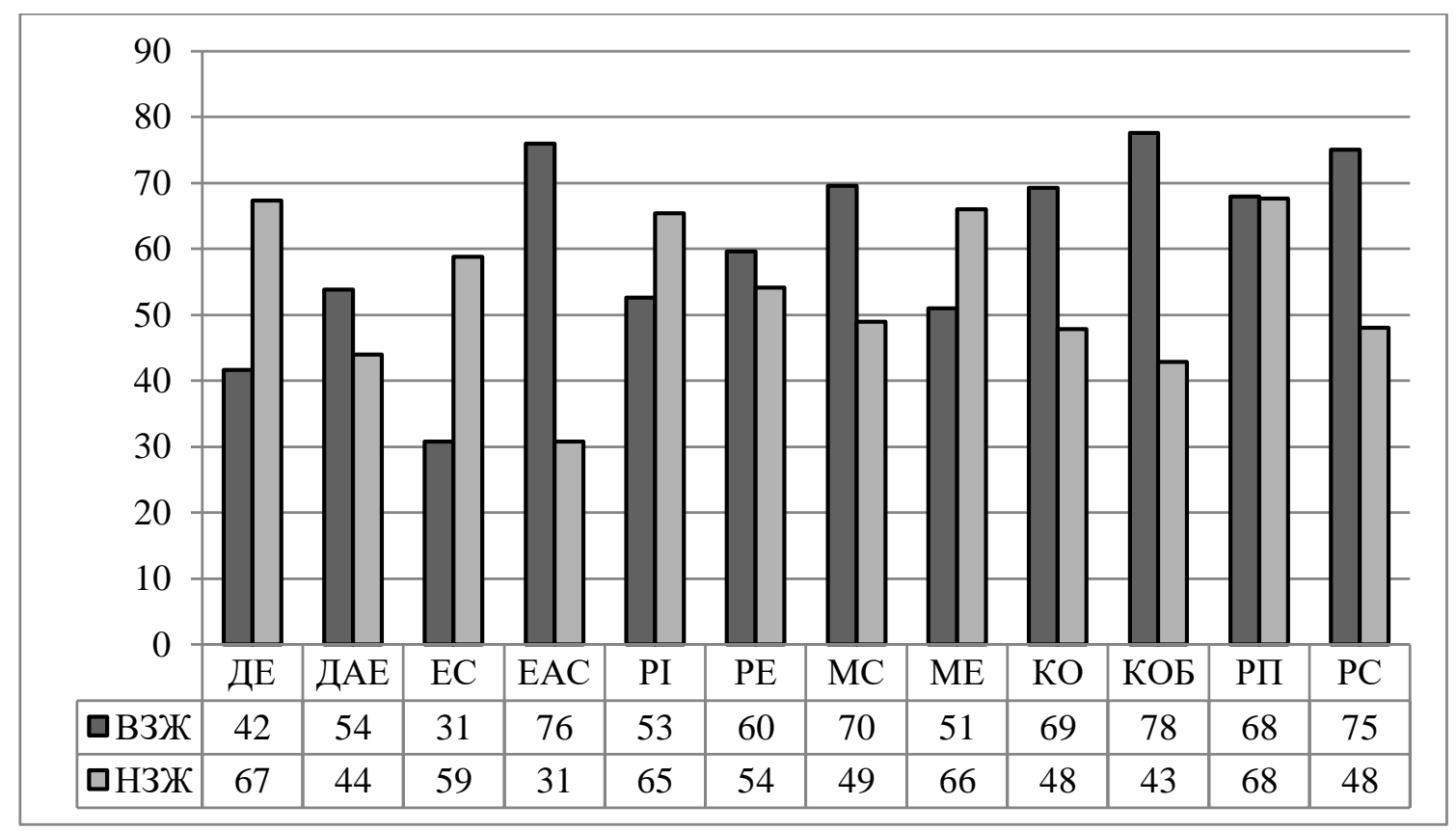

Рис. 3. Гістограма результатів діагностики функціональних компонентів оманливості

Примітки. Умовні скорочення: ДЕ - динамічна ергічність, ДАЕ - динамічна аергійність, ЕС - емоційна сиенічність, ЕАС - емоційна астенічність, РI - регуляторна інтернальність, РE - регуляторна екстернальність, МС - мотиваційна соиіоцентрованість, МЕ - мотиваційна егоцентрованість, КО - когнітивна осмисленість, КЛБ - когнітивна обізнаність, РП - результативність предметна, РС - результативність суб'єктна.

У групі юнаків з низьким рівнем задоволеності життям спостерігається тенденція до оманливої демонстрації активності, оперативності, прагнення бути кращим за інших (ДЕ). Для таких осіб характерна регуляторна інтернальність (PI), що виражається та проявляється у вигляді їх брехливої демонстрації самокритики, незалежності, власної значимості. Слід відмітити, що представники цієї групи, як і особи іншої групи (ВЗЖ), демонструють спрямованість на соціально значущий результат, при прагненні самореалізації, бажанні досягти позитивних відносин із оточуючими. Також спостерігається тенденція до високих значень егоцентричної складової (ME), яка розглядається з позиції заперечення своєї незначущості, залежності від зовнішніх обставин, виражена в бажанні не звертати на себе увагу в процесі взаємодії, прагненні уникати особистих ускладнень, можливих покарань

Таким чином, проведений аналіз результатів діагностики оманливості показав наявність розбіжностей ії компонентного наповнення в структурі особистості юнацтва.

\section{Висновки}

Результати цього дослідження дають змогу зробити такі попередні висновки:

1. Явище задоволеності життям розглядається більшістю авторів як суб'єктивно переживаний стан, що $€$ реакцією на якість взаємодії індивіда з життєвими обставинами.
2. Серед чинників, що роблять вплив на задоволеність життям, в основному, виділяють: спадковість, самооцінку, особистісні характеристики, погляди на життя, настрій, здоров'я та вік, культуру та інтелект, родинне щастя, батькіство чи кар'єрне зростання, шлюб та щастя в ньому, заробітна плата, економічний стан в країні, пандемії, комфортне місце проживання та країну (клімат, екологія, розвинена соціальна інфраструктура), особливості роботи системи охорони здоров'я, уряду так багато інших.

3. Схильність до брехні у юнаків обумовлена віковими, особовими, гендерними, культурно-обумовленими, середовищними та інтелектуальними особливостями.

4. Проведений кореляційний аналіз його результатів підтверджує припущення щодо взаємопов'язаності та взаємовпливи досліджуваних показників омани та задоволеності життям.

5. Визначено групи осіб з високим і низьким рівнем задоволеності життям (за Е. Дінером), що дало змогу дослідити психологічні особливості прояву обману, мотивації щодо застосування омани у повсякденному житті у будь-яких сферах життєдіяльності та вивчення особливості змістовного наповнення компонентів оманливості у представників юнацького віку.

6. Встановлено, що респонденти з високим рівнем задоволення життям можуть використовувати оману, щоб не зіпсувати враження про себе, вони схильні при 
знайомстві прикрашати себе, щоб створити хороше враження, важливим є острах закидів з боку. Їм притаманна емоційна астенічність, що проявляється нещирістю, у запереченні негативних емоцій: гніву, злості, грубості; оманливе заперечення своєї непоінформованості під час прийняття рішень; оманливе заперечення спрямованості на особистісно-значимий результат, нездатність до самореалізації, а також брехлива демонстрація власної значущості у вирішенні суспільних питань, конфліктах, що виражена у бажанні бути серед людей, колективу, суспільства, переважанням суспільних інтересів над особистими інтересами.

7. Особи з низьким рівнем задоволеності життям можуть спотворювати інформацію про себе, щоб не зіпсувати відносин із оточуючими та обмаюють близь-

\section{Література}

1. Аргайл М. Психология СЧАСТЬЯ. 2- е изд. СПб. : Питер, 2003. 271 с.

2. Балацкий Е. В. Факторы удовлетворённости жизнью: измерение и интегральные показатели. Мониторинг общественного мнения № 4 (76), октябрь - декабрь 2005, С. 42-52.

3. Баришполець О. Т. Омана в інформаційному просторі та міжособовій комунікації: монографія. Національна академія педагогічних наук України, Інститут соціальної та політичної психології. Кіровоград : Імекс Лтд, 2013, 648 с.

4. Бенко Е. В. Обзор зарубежных публикаций, посвящённых исследованию благополучия. Вестник ЮурГУ, Т8 (№2). 2015 С. 5- 13.

5. Джидарьян И. А. Психология счастья и оптимизма. Изд. «Институт психологии РАН». М., 2013.

6. Зинченко Е. В. Содержание представлений студентов о лжи. Актуальные вопросы философии и методики преподавания иностранных языков. Межвузовский сборник научных статей. В 2-х частях. Часть 1. Ростов-Н.Д: Изд. РИНЯЗ, 2005, С. 214-220.

7. Знаков В. В. Психология понимания правды. СПб.: Алетейя, 2013. 281 с.

8. Косьянова О. Ю., Чебикін О. Я. Використання поліграфа та методики емоційної зрілості для оцінки схильності до обману. Монографія. Одеса: ТОВ «Лерадрук», 2017. $224 \mathrm{c}$.

9. Любомирски Соня. Психология счастья. Новый подход. Питер, 2014, 364 с.

10. Прядеин В. П. Психодиагностика личности: Избранные психологические тесты: Практикум. Сургут : Сургутский гос. пед. ун-т, 2014. 215 с.

11. Райгородский Д. Я. Практическая психодиагностика. Самара. 2001.

12. Селигман Мартин. Новая позитивная психология: Научный взгляд на счастье и смысл жизни. М.: София, 2006, 368 с.

13. Церковная И. А. Многомерно-функциональное исследование лживости как индивидуально-психологической особенности личности: дис. ...канд. психол. наук. Екатеринбург, 2005. 183 с.

14. Шкуратова И. П., Крикало Е. Л. Отношение студентов к разным видам своей и чужой лжи. Инди- ких, щоб їх не засмучувати. У таких юнаків спостерігається тенденція до оманливої демонстрації активності, оперативності, демонстрація прагнення бути кращим за інших. Для них характерна регуляторна інтернальність, що виражається та проявляється у вигляді їх брехливої демонстрації самокритики, незалежності, власної значимості. Можуть застосовувати певні механізми оманливості задля досягнення позитивних стосунків з оточенням. Також такі особи демонструють егоцентричність, яка розглядається 3 позиції заперечення своєї незначущості, залежності від зовнішніх обставин, виражена в бажанні не звертати на себе увагу в процесі взаємодії, прагненні уникати особистих ускладнень, можливих покарань.

видуальные различия в познании и общении. Ростовна-Дону : Антей, 2007. С. 266-284.

15. Bartram David. Age and Life Satisfaction: Getting Control Variables under Control (англ.) Sociology. 2021. Vol. 55, iss. 2. P. 421-437. ISSN 0038-0385. DOI: https://doi.org/10.1177/0038038520926871

16. Diener E., \& Lucas R. E. Personality and subjective well-being. In D. Kahneman, E. Diener, \& N. Schwarz (Eds.). Well-being: The foundations of hedonic psychology, 1999, pp. 213-229

17. Glenn N. Is the apparent U-shape of well-being over the life course a result of inappropriate use of control variables? A commentary on Blanchflower and Oswald. Social Science \& Medicine. 69 (4), 2009. Pp. 481- 485.

18. Goldbeck Lutz; Schmitz Tim G.; Besier Tanja; Herschbach Peter; Henrich, Gerhard. Life satisfaction decreases during adolescence. Quality of Life Research. 2007. 16 (6). Pp. 969-979.

\section{References}

1. Argyll, M. (2003). Psikhologiya SCHASTYA [Psychology of HAPPINESS]. Saint Petersburg: Peter [in Russian].

2. Balatsky, E. V. (2005). Faktory udovletvoryonnosti zhiznyu: izmerenie i integralnye pokazateli [Factors of satisfaction with life: measurement and integral indicators]. Monitoring obshchestvennogo mneniya - Public Opinion Monitoring, 4 (76), 42-52 (October - December) [in Russian].

3. Bartram, David. (2021). Age and Life Satisfaction: Getting Control Variables under Control. Sociology, 22(55), 421-437 [in English].

4. Baryshpolets, O. T. (2013). Omana v informatsiinomu prostori ta mizhosobovii komunikatsii [Delusion in the information space and interpersonal communication]. Natsionalna akademiia pedahohichnikh nauk Ukrainy, Institut sotsialnoi ta politichnoi psikholohii [National Academy of Pedagogical Sciences of Ukraine, Institute of Social and Political Psychology]. Kirovograd: Imex Ltd [in Ukrainian].

5. Benko, E. V. (2015). Obzor zarubezhnykh publikatsiy, posvyashchyonnykh issledovaniyu blahopoluchiya [Review of foreign publications devoted to the study of well-being]. Vestnik YyurGU-Bulletin of the 
South Ural State University, 8 (2), 5-13 [in Russian].

6. Diener, E., \& Lucas, R. E. (1999). Personality and subjective well-being. In D. Kahneman, E. Diener, \& N. Schwarz (Eds.). Well-being: The foundations of hedonic psychology, 213-229 [in English].

7. Dzhidaryan, I. A. (2013). Psikhologiya schastya $i$ optimizma [Psychology of happiness and optimism]. Institute of Psychology RAS Publishing House. Moscow [in Russian].

8. Glenn, N. (2009). Is the apparent U-shape of wellbeing over the life course a result of inappropriate use of control variables? A commentary on Blanchflower and Oswald. Social Science \& Medicine, 69 (4), 481-485 [in English].

9. Goldbeck, Lutz; Schmitz, Tim G.; Besier, Tanja; Herschbach, Peter; Henrich, Gerhard (2007). Life satisfaction decreases during adolescence. Quality of Life Research, 16 (6), 969-979 [in English].

10. Kosianova, O. Yu., Chebykin, O. Ya. (2017). Vikoristannia poligrafa ta metodiki emotsiinoi zrilosti dlia otsinki shilnosti do obmanu [The use of polygraph and methods of emotional maturity to assess the propensity to deceive]. Odesa: Leradruk LLC [in Ukrainian].

11. Lubomirski, Sonya (2014). Psikhologiya schastya. Novyi podhod [The psychology of happiness. A new approach]. Piter [in Russian].

12. Pryadein, V. P. (2014). Psikhodiagnostika lichnosti: Izbrannye psikhologicheskie testy: Praktikum [Psychodiagnostics of personality: Selected psychological tests: Workshop]. Surgut: Surgut State Pedagogical University [in Russian].
13. Raigorodsky, D. Ya. (2001). Prakticheskaya psikhodiagnostika [Practical psychodiagnostics]. Samara [in Russian].

14. Seligman, Martin (2006). Novaya pozitivnaya psikhologiya: Nauchny vzglyad na schastie i smysl zhizni [New Positive Psychology: A Scientific Look at Happiness and the Meaning of Life]. Moscow: Sofia [in Russian].

15. Shkuratova, I. P., Krikalo, E. L. (2007). Otnoshenie studentov $\mathrm{k}$ raznym vidam svoey i chuzhoy lzhi [The attitude of students to different types of their own and other people's lies]. Individualnye razlichiya $v$ poznanii i obshchenii - Individual differences in cognition and communication, 266-284. Rostov-on-Don: Antey [in Russian].

16. Tserkovnaya, I. A. (2005). Mnogomernofunktsionalnoe issledovanie lzhivosti kak individualnopsikhologicheskoy osobennosti lichnosti [Multidimensional functional study of falsehood as an individual psychological personality trait]. Candidate's thesis. Ekaterinburg [in Russian].

17. Zinchenko, E. V. (2005). Soderzhanie predstavlenii studentov o lzhi [The content of students' ideas about lies. Aktualnye voprosy filosofii i metodiki prepodavaniya inostrannykh yazykov [Topical issues of philosophy and methods of teaching foreign languages. Interuniversity collection of scientific articles]. Mezhvuzovskiy sbornik nauchnykh statey - Interuniversity collection of scientific articles, part 1, 214-220. Rostovon-Don: Ed. RINYAZ [in Russian].

18. Znakov, V. V. (2013). Psikhologiya ponimaniya pravdy [Psychology of understanding the truth]. Saint Petersburg: Aleteya [in Russian].

Olena Kosianova,

PhD (Candidate of Psychological Sciences), docent of the Department of Theory and Methods of Practical Psychology, The State institution "South Ukrainian National Pedagogical University named after K. D. Ushynsky”, 26, Staroportofrankivska Str., Odessa, Ukraine,

Olena Nazaruk,

Master of Psychology,

The State institution "South Ukrainian National Pedagogical University named after K. D. Ushynsky", 26, Staroportofrankivska Str., Odessa, Ukraine

\section{FEATURES OF LIFE SATISFACTION AND DECEPTIVENESS IN ADOLESCENCE}

Many researchers in various fields of psychology, as well as specialists who are not related to psychological study, such as sociologists, political scientists, economists, have considered such a phenomenon as "life satisfaction" in recent decades. There is also a heightened interest in life satisfaction in the applied aspect. The state of the personality in the psychological point of view is determined more often by emotional stability, stress resistance, high motivation, therefore, in a word, harmonious relations in the world around and with oneself. The researchers are faced with the question: "How can you achieve life satisfaction using such a harmonious construction?". Life satisfaction can act as a constant feature and tool for achieving and realizing a person's life path in general. This phenomenon is associated in psychological studies with such names as: M. Argyle, A. Maslow, V. Frankl, R. R. May, E. Benko, etc. According to the general life satisfaction, which is closely related to the given problem of important aspects of life (self-esteem; family; friendship; social aspects, such as: work, learning activity; economic and social status, etc.). In the meantime, all these person`s spheres of life are closely connected with one more phenomenon, namely the deceptiveness of personality. But as the study of different age periods shows, it is especially important that the characteristic feature of the personality is manifested in adolescents. It is in this age and the propensity to deceive can influence the future behavioral strategies and leave a mark on the whole path of life. The aim of this study was to find the features of life satisfaction and the specifics of delusional personality in adolescence. A total of 48 young people aged 18 to 23 took part in the study. The following research methods were used: 
theoretical (classification, structuring and analysis of approaches to the study and understanding of delusion and life satisfaction in the psychological literature); empirical (test methods: Life Satisfaction Questionnaire (M. M. Melnikova), The Satisfaction With Life Scale (SWSL; E. Diner (1985)); Multidimensional-Functional Diagnosis of Lies (V. P. Pryadein, I. A. Tserkovnikov), "Motives of Telling Lies" by I. P. Shkuratova, as well as mathematical and statistical (data processing was done using Microsoft Excel, SPSS 26.0 for Windows XP). The correlation analysis revealed the presence of significant positive and negative relationships at the level of $1 \%$ and $5 \%$ between the causes and motivations of delusion, its components with life satisfaction. The obtained correlation relationships confirm the assumptions about the interconnectedness and mutual influence of the studied indicators of delusion and life satisfaction. The groups of subjects with high and low level of life satisfaction (according to E. Diner) were determined: the group with high value indicator of the general level of life satisfaction (HLS, $n=12$ ) and the group with low value indicator of the general level of life satisfaction (LLS, $\mathrm{n}=16$ ), which made it possible to study the psychological features of deception, motivation to use deceptiveness in everyday life in all spheres of life and study the peculiarities of the content of the components of motivation to use deceptiveness in adolescence.

Keywords: life satisfaction, deceptiveness of personality, motives and reasons for deception, general level of life satisfaction.

Подано до редакиії 01.12.2021

УДК: 159.9:616.8

DOI: https://doi.org/10.24195/2414-4665-2021-4-6

Вікторія Мендело,

аспирант кафедры теории и методики практической психологии, Государственное учреждение «Южноукраинский национальный педагогический университет имени К. Д. Уиинського», ул. Старопортофранковская, 26, г. Одесса, Украина

\section{О ТЕНДЕНЦИЯХ ИССЛЕДОВАНИЯ ЭМОЦИОНАЛЬНОГО ИНТЕЛЛЕКТА}

В статье рассмотрен проиесс исторического развития понятия «эмоциональный интеллект», а такюе произведена классификация современных подходов к данному явлению в отечественных и зарубежных научных трудах. Цель исследования: систематизировать тенденции исследования эмоционального интеллекта как компонента мышления. Для достижения этой цели были решены следующие задачи: уточнить психологическую сущңность значения понятия «эмоциональный интеллект»; обобщить и систематизировать основные признаки, по которым проводятся исследования эмоционального интеллекта; охарактеризовать психологические модели эмоционального интеллекта. Для решения поставленных задач использовался следующий комплекс теоретических методов исследования: изучение и анализ психологической литературы по теме исследования, обобщение и систематизация материала, что дало возможность охарактеризовать основные аспекты $и$ направления, по которым ведутся научные изыскания. Научная статья является обобщающим систематическим исследованием. Методологической основой исследования являются научные труды отечественных и зарубежных ученых-психологов, таких как: Дж. Майер, Д. Халперн, У. Грей, А. Ортони, Дж. Клор, А. Коллинз, а также Л. С. Выготский, С. Л. Рубинштейн, А. Н. Леонтьев, О. К. Тихомиров, О. Я. Чебыкина и др. В ходе исследования установлено, что: несмотря на большое количество исследований видов и компонентов интеллекта, окончательное их установление на данный момент является крайне затруднительньм. В результате проведённого исследования отмечено, что наиболее эффективно раскрывают понятие эмоционального интеллекта модели способностей, поскольку они характеризуются большей практической разработкой и большей надёжностью диагностического инвентаря.

Ключевые слова: эмоции, эмоциональный интеллект, модели эмоционального интеллекта, эмоциональное мыцление, эмочиональная зрелость, история психологии. 